\title{
Comunidade Virtual de Antropologia
}

A Comunidade Virtual de Antropologia (CVA) foi criada em setembro de 1999 por um grupo de pesquisadores, cujo principal interesse concentra-se em torno do conhecimento antropológico. Pensado como um complemento às redes acadêmicas de informação, o site contribui na orientação do público em relação à antropologia, seja como profissão, como conhecimento especializado de relevância para práticas de cunho social ou como fonte de informaçôes sobre a diversidade cultural.

A CVA procura adensar a comunicação entre interessados na área, dentro e fora do espaço acadêmico, criar novos canais para a pesquisa e sua divulgação e facilitar o acesso mais geral à vasta produçáo antropológica, recorrendo para tanto aos novos recursos de publicação e comunicação que a internet congrega. Nesta perspectiva, a CVA se utiliza das muitas afinidades entre a web e a antropologia: ambas se interessam por formas diversas de sociabilidade, promovem fluxos alternativos de informação, somam e contrastam pontos de vista e acumulam saberes oriundos das experiências humanas mais diversas. Fator a ser ressaltado é a interação que se produz entre especialistas e "leigos", o que favorece a reflexão e o debate sobre a diversidade cultural, possibilitando a superação de situaçóes de exclusão e preconceito e o fortalecimento da cidadania pelo reconhecimento da diferença.

Constatada uma lacuna em relação à dificuldade de publicação e divulgaçẫo do acervo de pesquisas e produçóes antropológicas existentes (teses, dissertaçóes, monografias, artigos), bem como a pouca visibilidade desses trabalhos e a falta de dinamicidade na troca de informaçôes entre estudiosos, a CVA propõe a superação dessa lacuna através do desenvolvimento de uma rede. Conseqüência importante é o retorno do conhecimento produzido para a sociedade em geral, pela intensa difusão das informaçóes para além dos limites institucionais das universidades e de grupos especializados. Por meio de acesso livre e gratuito, ao longo destes oito anos de funcionamento ininterrupto, o site vem ajudando a promover na web a democratização do conhecimento produzido, tornando visíveis idéias, pensamentos, conceitos, discursos e práticas sociais.

\section{A equipe}

Para viabilizar a CVA, foi formada uma equipe de colaboradores "permanentes", responsáveis pela seleção, organização e sistematização das informaçôes antropológicas e etnográficas. Trabalhando de forma voluntária e a partir de diferentes regiôes do país (SC, MG, RJ, CE, $\mathrm{SP}$ ), esta equipe utiliza as ferramentas interativas disponíveis na internet para planejar, organizar e executar suas atividades, selecionando, organizando e sistematizando as informaçôes de cunho antropológico. A CVA oferece ainda espaço de interação com a sociedade através da hospedagem de sites de comunidades detentoras de saberes locais.

Embora operando no Brasil e com seus conteúdos publicados prioritariamente em língua portuguesa, a CVA ultrapassou as fronteiras nacionais, mantendo intercâmbio com pesquisadores da África (Moçambique e Angola), Europa (França, Itália, Portugal) e América do Norte (Canadá). As estatísticas de visitação ao site e de cadastro de interessados em receber informaçôes 
através de endereço eletrônico (e-mail) mostram a participação de docentes, estudantes e pesquisadores que buscam na CVA subsídios também para suas respectivas açóes educativas (professores e alunos de ensino fundamental e médio e de nível universitário, entre outros).

\section{Circulação de idéias e pensamentos}

A experiência adquirida ao longo destes oito anos de funcionamento ininterrupto aponta para $\mathrm{o}$ fato de que a iniciativa náo se restringe a uma determinada comunidade (acadêmica, profissional ou cultural); ao contrário, ela compromete-se com a promoção da diversidade - de idéias, pensamentos, conceitos, discursos e práticas sociais.

Sabemos que a internet abre novas oportunidades de interação, acesso e democratização do conhecimento e, ao mesmo tempo, gera a demanda pela qualidade e fluxo constante das informaçôes. Nesse sentido, as atualizações do site acontecem mensalmente, sendo publicado conteúdo de relevância para o campo antropológico em cada uma das seções: Artigo, Coluna, Entrevista, Resenha, Divulgando seu Trabalho (teses, dissertaçóes, monografias), Notícias da Comunidade, Site do Mês (indicado por internautas), Tribo (subsites Infância e Gênero; sites de pesquisa; de eventos; páginas pessoais). Em cada seção, os/as interessados/as encontram as normas para envio das diferentes modalidades de trabalhos, bem como os e-mails dos/as respectivos/as coordenadores/as de seção. Participe enviando conteúdo, informaçóes sobre pesquisas em andamento, concursos, sites pessoais de interesse para a antropologia, críticas e sugestôes. Ingresse na comunidade.

\author{
SÍTIO ELETRÔNICO \\ www.antropologia.com.br \\ CONTATOS \\ faleconosco@antropologia.com.br
}

EQUIPE

Coordenadora Geral: Renata Apgaua

Supervisor Editorial: Fernando César Araújo

Coordenador Científico da Área de Projetos: Oscar Calávia Sáez

Area de Projetos: Marta Magda A. Machado

Coordenadora da Seção "Artigo": Andrea Lissett Pérez

Coordenadora da Seção "Entrevista": Gláucia Buratto Rodrigues de Mello

Coordenadora da Seção "Resenha": Isabel Travancas

Coordenadora da Seção "Divulgando seu Trabalho": Liliane Brum Ribeiro

Coordenadores da Seção "Coluna": Rogério Lopes Azize e Samira Feldman Marzochi 